\title{
PENGEMBANGAN SISTEM PENDUKUNG KEPUTUSAN BERBASIS MOBILE UNTUK PENGISIAN KARTU RENCANA STUDI DENGAN FUZZY MULTI-ATTRIBUTE DECISION MAKING (FMADM) METODE SIMPLE ADDITIVE WEIGHTING (SAW) DI JURUSAN PENDIDIKAN TEKNIK INFORMATIKA UNIVERSITAS PENDIDIKAN GANESHA SINGARAJA
}

\author{
Anak Agung Gde Putra Ajiwerdhi, Made Windu Antara Kesiman, I Made Agus \\ Wirawan \\ Jurusan Pendidikan Teknik Informatika \\ Universitas Pendidikan Ganesha \\ email: dekndu@yahoo.com, kadexjus@yahoo.com
}

\begin{abstract}
ABSTRAK
Kartu Rencana Studi (KRS) adalah kartu yang berisi daftar matakuliah yang diikuti oleh setiap mahasiswa dalam satu semester. Setiap mahasiswa harus mengisi KRS untuk menentukan matakuliah yang akan diambil setiap semesternya. Seiring perkembangan teknologi di masa sekarang ini Jurusan Pendidikan Teknik Informatika telah mengembangkan sebuah perangkat lunak KRS mobile. Namun perangkat lunak yang dikembangkan masih terbatas pada proses pengisian KRS saja dan belum mampu membantu mahasiswa dalam memilih matakuliah yang akan diambil sehingga proses pengisian KRS memerlukan waktu yang cukup lama. Berdasarkan permasalahan tersebut perlu dikembangkan sebuah aplikasi yang dapat membantu mahasiswa dalam memilih matakuliah saat pengisian KRS.

Untuk membantu mahasiswa memilih matakuliah dalam pengisian KRS diperlukan sebuah sistem pendukung keputusan (SPK). SPK ini merupakan sistem yang dapat membantu mahasiswa mengambil keputusan dengan melengkapi mahasiswa dengan informasi mengenai matakuliah yang disarankan dan tidak disarankan untuk diambil saat pengisian KRS. Sehingga sistem ini tidak dimaksudkan untuk menggantikan mahasiswa dalam pengambilan keputusan. Sedangkan model yang digunakan dalam SPK ini adalah Fuzzy Multi-Atribute Decision Making (FMADM) dengan metode Simple Additive Weighting (SAW).

Hasil penelitian ini berupa aplikasi berbasis mobile phone yang digunakan untuk mengakses SPK pengisian KRS dan aplikasi web yang digunakan untuk mengelola data untuk proses SPK pada aplikasi mobile. Aplikasi ini dibangun menggunakan bahasa pemprograman Java yaitu J2ME dan PHP serta MySQL sebagai databasenya. Dengan adanya perangkat lunak ini akan memudahkan mahasiswa dalam memilih matakuliah yang akan diambil saat pengisian KRS setiap semesternya.
\end{abstract}

Kata kunci: kartu rencana studi, sistem pendukung keputusan, FMADM, SAW, mobile phone 


\begin{abstract}
Study planning card is a card of lecturs list attended by every student in one semester. Every student has to fill study planning card to decide lecturs which have to be taken in each semester. As the development of technology nowadays, Informatics Engineering Education Department has developed a software, it is mobile study planning card. However, the software that is developed is still limited an the filling of study planning card only and has not able to help the students get in choosing lecturs that will be taken, so that the process of filling study planning card needs much time. Based on that problem, it is needed to develop an application which is able to help students in choosing lecturs when they fill the study planning card.

For helping student to choose lecturs in filling study planning card, it is need a Decision Support Systems (DSS). DSS is a system which can help students in deciding by providing information for the students about what lecturs should be taken and what should be not. Therefore this system is not aimed to change the students in taking decision. Meanwhile, the model used in this DSS is FMADM with SAW method.

The result of this research is an application based mobile phone used for accessing DSS, filling study planning card and making web application, that are used to manage data for DSS process in mobile application. This application is made using J2ME and PHP, also MySQL as its database. This software will ease the students in choosing lecturs that will be taken in filling study planning card in each semester.
\end{abstract}

Key words : study planning card, decision support systems, FMADM, SAW, mobile phone

\title{
I. PENDAHULUAN
}

Kartu Rencana Studi (KRS) adalah kartu yang berisi daftar mata kuliah yang akan diikuti oleh setiap mahasiswa dalam satu semester. Pengisian KRS di setiap semesternya merupakan bagian yang berperan penting dalam sistem akademik setiap perguruan tinggi salah satunya Universitas Pendidikan Ganesha (Undiksha). Setiap mahasiswa harus mengisi KRS untuk menentukan mata kuliah yang akan diambil setiap semesternya. Hal ini menjadikan pengisian KRS sebagai hal yang vital bagi kelancaran perkuliahan mahasiswa karena jika mahasiswa tidak mengisi KRS maka mahasiswa bersangkutan dinyatakan cuti atau berhenti kuliah.

Seiring dengan perkembangan teknologi dan komunikasi di masa sekarang ini, Jurusan Pendidikan Teknik Informatika telah mengembangkan aplikasi KRS berbasis mobile. KRS berbasis mobile atau KRS mobile ini merupakan salah satu alternatif untuk mengakses form pengisian KRS. Dengan adanya KRS mobile memudahkan setiap mahasiswa dalam pengisian KRS setiap semesternya karena untuk mengisi KRS, mahasiswa tidak lagi harus mencari warung internet (warnet) atau area hostpot uuntuk membuka halaman web melalui komputer atau laptop. Namun perangkat lunak yang dikembangkan masih terbatas pada proses pengisian KRS saja dan belum mampu membantu mahasiswa dalam memilih matakuliah yang akan diambil sehingga proses pengisian KRS memerlukan waktu yang cukup lama. 
Untuk membantu mahasiswa memilih matakuliah dalam pengisian KRS diperlukan sebuah sistem pendukung keputusan (SPK). Menurut Alter dalam Kusrini (2007), SPK merupakan sistem informasi interaktif yang menyediakan informasi, pemodelan dan pemanipulasian data. Sistem ini tidak dimaksudkan untuk menggantikan mahasiswa atau pembimbing akademik dalam proses pembuatan keputusan. Fuzzy Mutiple-Attribute Decision Making (FMADM) merupakan salah model yang dapat digunakan dalam penyelesaian SPK. FMADM adalah suatu model yang digunakan untuk mencari alternatif optimal dari sejumlah alternatif dengan atribut tertentu. Dalam menyelesaikan masalah FMADM metode yang dapat digunakan salah satunya adalah Simple Additive Weighting (SAW). SAW merupakan metode yang paling sederhana untuk menurunkan bobot atribut atau kriteria (Kusumadewi, 2006). Konsep dasar metode SAW adalah mencari penjumlahan terbobot dari rating kinerja pada setiap alternatif dari semua atribut. Hal ini membuat metode SAW cocok untuk digunakan dalam pembuatan perangkat lunak berbasis mobile yang memiliki jumlah memori terbatas, sedikit daya dari baterai, layar yang kecil dan bandwith jaringan yang rendah.

\section{KAJIAN PUSTAKA}

\subsection{Kartu Rencana Studi}

Kartu Rencana Studi (KRS) adalah sebuah kartu atau borang (form) yang berisi tentang jumlah dan jenis matakuliah yang harus diambil atau diprogram, sesuai dengan hasil prestasi mahasiswa pada semester sebelumnya dan prasyarat tiap matakuliah. Pengisian KRS dilaksanakan pada awal semester sebelum perkuliahan berlangsung. Sebelum mengisi KRS setiap mahasiswa akan mendapatkan Kartu Hasil Studi (KHS) semester sebelumnya. KHS ini berisikan nilai-nilai dari matakuliah yang diambil pada semester sebelumnya, Indeks Prestasi Semester (IPS) dan Indeks Prestasi Komulatif (IPK). IPS yang ada pada KHS semester sebelumnya yang akan menentukan berapa jumlah SKS maksimal yang dapat diambil oleh mahasiswa. Sebelum pengisian KRS umumnya mahasiswa melakukan beberapa hal seperti mengecek matakuliah yang keluar pada semester ini, mengecek nilai-nilai matakuliah pada semester sebelumnya kemudian menkonsultasikan matakuliah yang akan diambil dengan Pembimbng Akedemik (PA).

\subsection{Sistem Pendukung Keputusan}

Sistem Pendukung Keputusan (SPK) atau Decision Support Systems (DSS) pada awalnya diciptakan oleh dua professor di MIT (Anthony Gorry dan Michael S.Morton) pada tahun 70-an. Menurut mereka DSS harus diarahkan untuk mendukung manajemen pada masalah-masalah yang semi-structured (semi-terstruktur), yaitu masalah yang memiliki informasi kurang lengkap sehingga para manajer ragu dalam mengambil keputusan. DSS akan memberi dukungan atau alternatif penyelesaian sehingga para manajer dapat menguji alternatif ini untuk memilih mana yang terbaik. (Akib, 2009). Menurut Alter dalam Kusrini (2007), DSS merupakan sistem informasi interaktif yang menyediakan informasi, pemodelan dan pemanipulasian data. Sistem ini digunakan untuk membantu pengambilan keputusan dalam situasi yang semi terstruktur dan situasi yang tidak terstruktur, dimana tak seorang pun tahu secara pasti bagaimana keputusan seharusnya dibuat.

Arsitektur dari sistem pendukung keputusan dapat dilihat pada Gambar 1. 


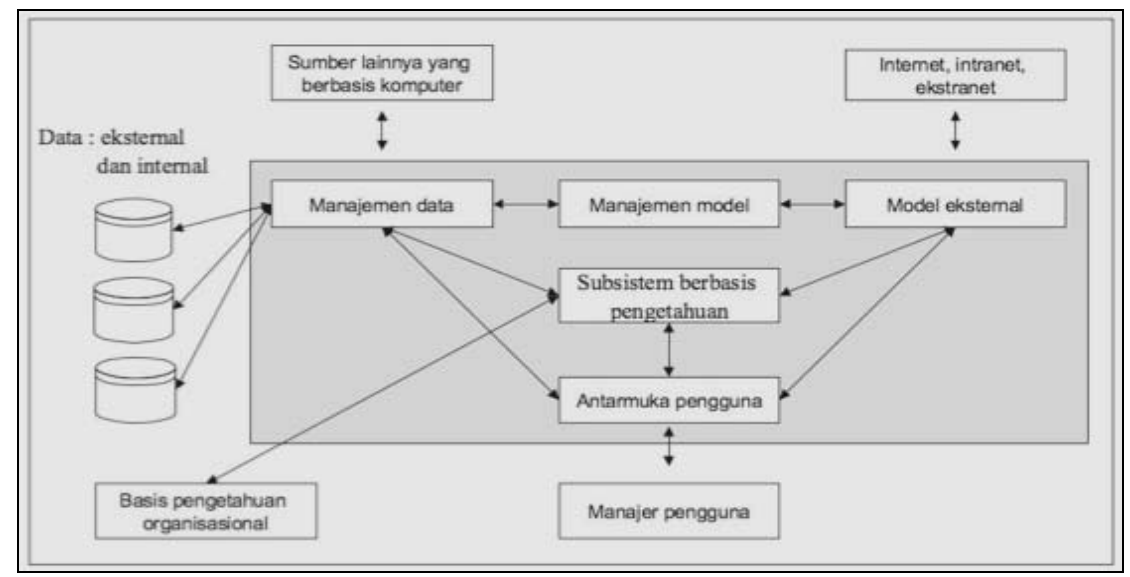

Gambar 1 Arsitektur dari Sistem Pendukung Keputusan

(Sumber : Laymond, 2010)

\subsection{Fuzzy Multiple Attribute Decision Making}

FMADM adalah suatu metode yang digunakan untuk mencari alternatif optimal dari sejumlah alternatif dengan kriteria (atribut) tertentu. Inti dari FMADM adalah menentukan nilai bobot untuk setiap atribut, kemudian dilanjutkan dengan proses perangkingan yang akan menyeleksi alternatif yang sudah diberikan (Wibowo S, 2009). Sebagian besar pendeketan FMADM dilakukan melalui 2 langkah, yaitu : pertama, membuat rating pada setiap alternatif berdasarkan agregasi drajat kecocokan pada semua kriteria; kedua melakukan perangkingan alternatif-alternatif keputusan tersebut. Dengan demikian, bisa dikatakan bahwa, masalah FMADM adalah mengevaluasi $\mathrm{m}$ alternatif $\mathrm{A}_{i}(\mathrm{i}=1,2, \ldots, \mathrm{m})$ terhadap sekumpulan atribut atau kriteria $\mathrm{C}_{j}(\mathrm{j}=1,2, \ldots, \mathrm{n})$, dimana setiap atribut saling tidak bergantung satu dengan yang lainnya. Matriks keputusan setiap alternatif terhadap setiap atribut, X, diberikan sebagai : (Kusumadewi, 2006).

$$
\mathbf{X}=\left[\begin{array}{cccc}
x 11 & x 12 & \ldots & x 1 n \\
x 21 & x 22 & \ldots & x 2 n \\
: & : & : & : \\
x m 1 & x m 2 & \ldots & x m n
\end{array}\right]
$$

Dimana $\mathrm{x}_{i j}$ merupakan rating kinerja alternatif ke-i terhadap atribut ke-j. Nilai bobot yang menunjukkan tingkat kepentingan relatif setiap atribut, diberikan sebagai, $\mathrm{W}$ :

$\mathrm{W}=\{\mathrm{w} 1, \mathrm{w} 2, \ldots, \mathrm{wn}\}$

Rating kinerja (X), dan nilai bobot (W) merupakan nilai utama yang merepresentasikan preferensi absolute dari pengambil keputusan. Masalah FMADM diakhiri dengan proses perangkingan untuk mendapatkan alternatif terbaik yang diperoleh berdasarkan nilai keseluruhan preferensi yang diberikan.(Kusumadewi, 2006)

\subsection{Metode Simple Additive Weighting}

Metode SAW sering juga dikenal istilah metode penjumlahan terbobot. Konsep dasar metode SAW adalah mencari penjumlahan terbobot dari rating kinerja pada setiap alternatif dari semua atribut. Metode SAW membutuhkan proses normalisasi matriks 
keputusan (X) ke suatu skala yang dapat diperbandingkan dengan semua rating alternatif yang ada.

$$
r_{i j}= \begin{cases}\frac{x_{i j}}{\operatorname{Max}_{i}} & j i k a \mathrm{j} \text { atribut keuntungan (benefit) } \\ \frac{\operatorname{Min}_{i j}}{x_{i j}} & \text { jika j atribut biaya (cost) }\end{cases}
$$

dimana $\mathrm{r}_{i j}$ adalah rating kinerja ternormalisasi dari alternatif $\mathrm{A}_{i}$ pada atribut $\mathrm{C}_{j}$; $\mathrm{i}=1,2, \ldots, \mathrm{m}$ dan $\mathrm{j}=1,2, \ldots, \mathrm{n}$. Nilai preferensi untuk setiap alternatif $\left(\mathrm{V}_{i}\right)$ diberikan sebagai

$$
V_{i}=\sum_{j=1}^{n} w_{j} r_{i j}
$$

Nilai $\mathrm{V}_{i}$ yang lebih besar mengindikasikan bahwa alternatif $\mathrm{A}_{i}$ lebih terpilih.

\subsection{Java 2 Micro Edition}

J2ME adalah Java versi Sun yang ditujukan untuk mesin-mesin dengan sumber daya hardware yang terbatas seperti PDA, telepon seluler, dan elektronik konsumen dan perangkat embedded. Jadi bisa dikatakan J2ME adalah satu set spesifikasi dan teknologi yang fokus kepada perangkat konsumen. Perangkat ini memiliki jumlah memori yang terbatas, menghabiskan sedikit daya dari baterai, layar yang kecil dan bandwith jaringan yang rendah (Oracle, 2011).

J2ME menyediakan suatu interface yang sesuai dengan perangkat. Aplikasiaplikasi tersebut tidak harus dikompile ulang supaya mampu dijalankan pada mesin yang berbeda. Inti dari J2ME terletak pada configuration dan profile-profile. Suatu configuration menggambarkan lingkungan runtime dasar dari suatu sistem J2ME. Ia menggambarkan core library, virtual machine, fitur keamanan dan jaringan. J2ME sendiri ini dibagi menjadi dua bagian diantaranya ialah bagian configuration dan profile.

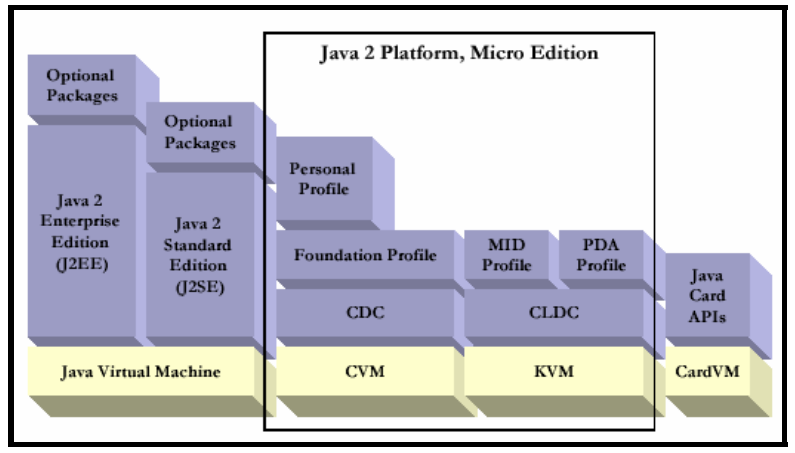

Gambar 2 Java 2 Micro Edition (Sumber : Prasetijo, 2005)

Dilihat dari Gambar 2, maka J2ME mempunyai lapisan konfigurasi dan profil yang didukung oleh Java Virtual Machine (CVirtual Machine dan K-Virtual Machine).

\section{ANALISIS DAN PERANCANGAN}

\subsection{Analisis Perangkat Lunak}

\subsubsection{Kebutuhan Perangkat Lunak}

Perangkat lunak yang dibangun merupakan aplikasi berbasis mobile. yang digunakan untuk mengakses SPK pengisian KRS. Selain itu untuk membantu proses SPK dalam aplikasi mobile penulis membuat aplikasi berbasis web yang digunakan 
administrator untuk mengelola data atribut dan variabel atribut yang digunakan dalam proses SPK. Perangkat lunak ini terdiri dari dua proses utama yaitu pemilihan matakuliah dan pemetaan matakuliah yang ada pada aplikasi mobile.

\subsubsection{Tujuan Pengembangan Perangkat Lunak}

Tujuan pengembangan SPK berbasis mobile untuk pengisian KRS adalah untuk membantu mahasiswa memilih matakuliah yang akan diambil dalam pengisian KRS setiap semesternya dan untuk memetakkan matakuliah pada semester selanjutnya sehingga dapat digunakan sebagai bahan pertimbangan dalam memilih matakuliah.

\subsubsection{Masukan dan Keluaran Perangkat Lunak}

Masukan untuk SPK berbasis mobile untuk pengisian KRS ini yaitu data mahasiswa, data matakuliah, data kelompok matakuliah, data detail kelompok matakuliah, data matakuliah prasyarat, data matakuliah prasyarat khusus, data matakuliah syarat, data nilai mahasiswa, data atribut dan variabel atribut sebagai bahan pertimbangan untuk mengambil keputusan, dan jumlah SKS maksimal yang bisa diambil per semester. Sedangkan keluaran dari sistem pendukung keputusan ini terdiri dari dua yaitu informasi matakuliah yang dapat digunakan sebagai bahan pertimbangan dalam pengisian dan informasi pemetaan matakuliah pada semester berikutnya.

\subsubsection{Model Fungsional}

Model fungsional dari SPK berbasis mobile untuk pengisian KRS ini dirancang menggunakan Data Flow Diagram (DFD). DFD merupakan alat yang digunakan pada metodologi pengembangan sistem yang terstruktur. DFD biasanya digunakan untuk menggambarkan suatu aplikasi yang telah ada atau aplikasi baru yang akan dikembangkan secara logika tanpa harus mempertimbangkan lingkungan fisik dimana data tersebut mengalir atau lingkungan fisik dimana data itu disimpan. Sehingga dapat menggambarkan arus data di dalam sistem secara terstruktur dan jelas (Wijaya,2009). Pada tahap analisis perangkat lunak, penggunaan notasi ini sangat membantu sekali di dalam komunikasi dengan pemakai sistem untuk memahami sistem secara logika. Model fungsional dari SPK berbasis mobile untuk pengisian KRS dalam bentuk diagram konteks yang dapat dilihat pada Gambar 3.

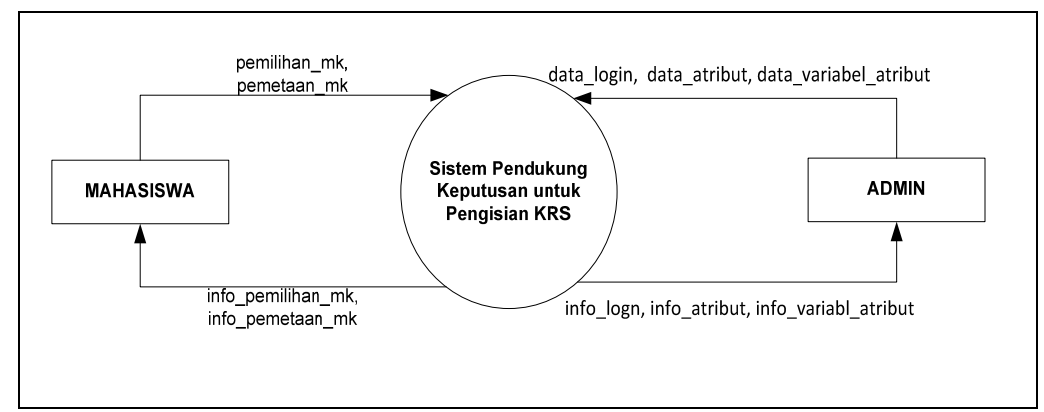

Gambar 3 Diagram Konteks SPK Untuk Pengisian KRS

\subsection{Perancangan Perangkat Lunak}

\subsubsection{Batasan Perancangan Perangkat Lunak}


Perangkat lunak yang dibangun adalah perangkat lunak berupa SPK untuk pengisian KRS. Perangkat lunak yang dibuat dirancang hanya untuk mahasiswa regular khususnya semester 2 ke atas yang akan mengambil matakuliah ke bawah atau ke atas atau kombinasi dan yang tidak dapat mengambil matakuliah yang disarankan.

\subsubsection{Perancangan Arsitektur Perangkat Lunak}

Rancangan arsitektur SPK untuk pengisian KRS terlihat pada gambar 3.8 Perangkat lunak pada sistem ini dibagi menjadi dua yaitu aplikasi mobile dan web. Aplikasi mobile merupakan aplikasi yang digunakan oleh mahasiswa untuk mengakses sistem ini, sedangkan aplikasi web merupakan fasilitas yang digunakan dosen untuk mengatur segala sesuatu yang berhubungan dengan sistem ini.

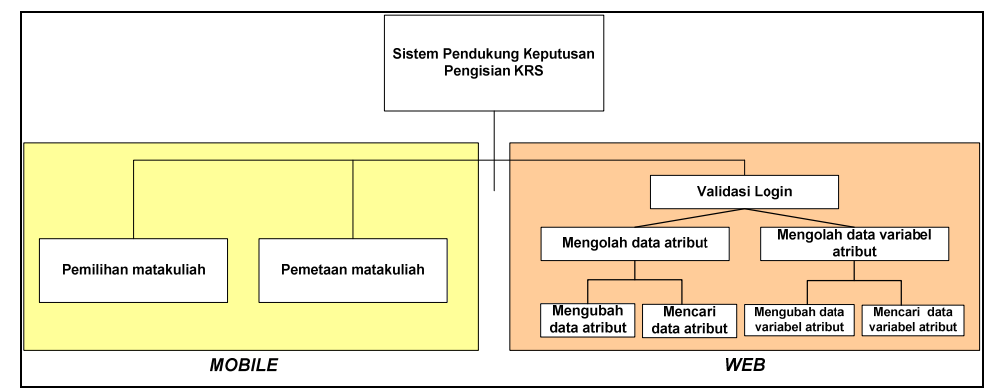

Gambar 4 Arsitektur SPK Untuk Pengisian KRS

\subsubsection{Perancangan Struktur Data}

Perancangan struktur data perangkat lunak merupakan tahap pendefinisian dari kebutuhan-kebutuhan fungsional dalam suatu tahap pengembangan sistem. Kebutuhankebutuhan fungsional yang dimaksudkan adalah isi file atau struktur dari tiap-tiap file yang diidentifikasi. Perancangan struktur data dari SPK untuk Pengisian KRS dijelaskan selengkapnya pada Gambar 5. 


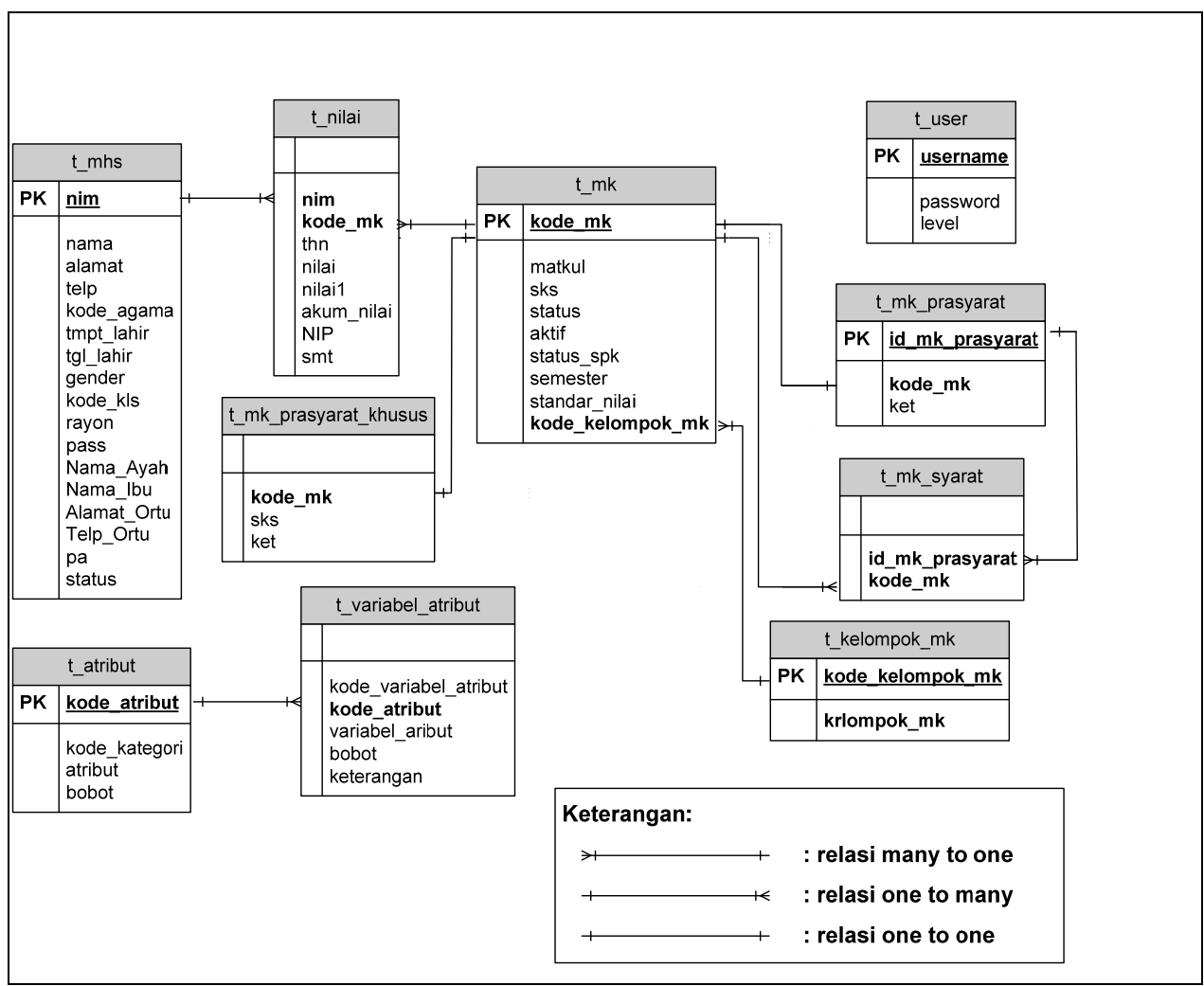

Gambar 5 Relasi Antartabel SPK Untuk Pengisian KRS

\subsubsection{Perancangan Antarmuka}

Rancangan antarmuka halaman SPK Berbasis Mobile untuk Pengisian KRS dapat dilihat pada Gambar 6 .

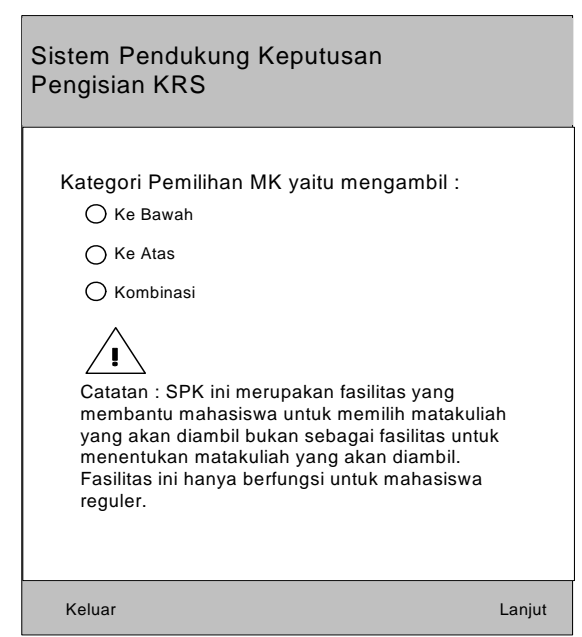

Gambar 6 Rancangan Antarmuka HalamanUtama SPK Berbasis Mobile untuk Pengisian KRS 


\section{IMPLEMENTASI PERANGKAT LUNAK}

Dari analisis dan perancangan yang telah dilakukan, langkah selanjutnya adalah melakukan implementasi perangkat lunak.

\subsection{Implementasi Arsitektur Perangkat Lunak}

Pada implementasi arsitektur perangkat lunak ini berupa hasil dari perancangan arsitektur perangkat lunak berupa unit-unit atau file-file kode program sesuai dengan lingkungan implementasi perangkat lunak. Berdasarkan perancangan sebelumnya implementasi arsitektur SPK berbasis mobile untuk pengisian KRS terdiri ari dua bagian yaitu bagian mobile dan bagian web. Implementasi arsitektur perangkat lunak ini pada bagian mobile dan bagian web selengkapnya dapat dilihat pada Tabel 1 dan Tabel 2

Tabel 1 Implementasi Arsitektur SPK Untuk Pengisian KRS Bagian Mobile

\begin{tabular}{|l|l|c|c|}
\hline \multirow{2}{*}{ No } & \multirow{2}{*}{ Rancangan } & \multicolumn{2}{|c|}{ Implementasi } \\
\cline { 3 - 4 } 1 & $\begin{array}{l}\text { Pemilihan } \\
\text { Matakuliah }\end{array}$ & $\begin{array}{r}\text { KrsMobile.java } \\
\text { LSpkPemilihanMk } \\
\text { LSpkPemilihanMk() }\end{array}$ & Spk_pemilihan_mk.php \\
\hline 2 & $\begin{array}{l}\text { Pemetaan } \\
\text { Matakuliah }\end{array}$ & $\begin{array}{r}\text { KrsMobile.java } \\
\text { LSpkPemilihanMk } \\
\text { LSpkPemilihanMk() }\end{array}$ & spk_pemetaan_mk.php \\
\hline
\end{tabular}

Tabel 2 Implementasi Arsitektur SPK Untuk Pengisian KRS Bagian Web

\begin{tabular}{|l|l|l|}
\hline No & Rancangan & \multicolumn{1}{c|}{ Implementasi } \\
\hline 1 & $\begin{array}{l}\text { Validasi } \\
\text { Login }\end{array}$ & Index.php \\
\hline 2 & $\begin{array}{l}\text { Mengolah } \\
\text { data atribut }\end{array}$ & $\begin{array}{l}\text { atribut.php } \\
\text { Lupdate_atribut.php }\end{array}$ \\
\hline 3 & $\begin{array}{l}\text { Mengolah } \\
\text { data variabel } \\
\text { atribut }\end{array}$ & $\begin{array}{l}\text { variabel_atribut.php } \\
\text { Lupdate_variabel_atribut.php }\end{array}$ \\
\hline
\end{tabular}

\subsection{Implementasi Struktur Data Perangkat Lunak}

Dalam pengimplementasian struktur data perangkat lunak ini, digunakan sebuah database dengan nama pti_siak. Berikut hasil implementasi struktur data SPK berbasis mobile untuk pengisian KRS.

1) Tabel User

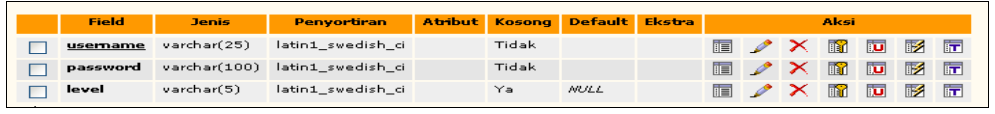

Gambar 7 Implemetasi Struktur Tabel User 
2) Tabel mahasiswa

\begin{tabular}{|c|c|c|c|c|c|c|c|c|c|c|c|c|c|}
\hline & Field & Jenis & Penyortiran & Atribut & Kosong & Default & Ekstra & \multicolumn{6}{|c|}{ Aksi } \\
\hline$\square$ & $\underline{\text { nim }}$ & varchar(15) & latin1_swedish_ci & & Tidak & & & 闻 & $\int x$ & 闂 & 四 & 成 & 可 \\
\hline$\square$ & nama & varchar(80) & latin1_5wedish_ci & & Tidak & & & 面 & $\Rightarrow x$ & 䨠 & 問 & 閣 & 演 \\
\hline$\square$ & alamat & varchar(100) & latin1_swedish_ci & & Tidak & & & 罡 & $\int x$ & 霜 & 成 & 蕆 & 闻 \\
\hline$\square$ & telp & varchar(20) & latin1_swedish_ci & & Tidak & & & 霞 & $\int x$ & 闻 & [0 & 蕆 & 泟 \\
\hline$\square$ & kode_agama & varchar(10) & latin1_swedish_ci & & Tidak & A1 & & 蕄 & $\int x$ & 阅 & [T] & 四 & F \\
\hline$\square$ & tmpt_lahir & varchar(80) & latin1_swedish_ci & & Tidak & & & 覧 & $\Rightarrow x$ & 電 & 笴 & 成 & 臣 \\
\hline$\square$ & tgl_lahir & date & & & Tidak & & & 覧 & $>x$ & 雷 & 勧 & 阁 & TT \\
\hline$\square$ & gender & varchar (20) & latin1_5wedish_ci & & Tidak & & & 面 & $\rho x$ & 麗 & 可 & 成 & 通 \\
\hline$\square$ & kode_kls & varchar (10) & latin1_swedish_ci & & Tidak & K3 & & 㖵 & $\int x$ & 间 & [I] & 咸 & 通 \\
\hline$\square$ & rayon & varchar(5) & latin1_swedish_ci & & Tidak & RO & & 艦 & $\Rightarrow x$ & 酺 & 可 & 蕆 & 筺 \\
\hline$\square$ & pass & varchar(100) & latin1_5wedish_ci & & Tidak & & & 貫 & $\int x$ & 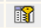 & 可 & 蕆 & 贀 \\
\hline$\square$ & Nama_Ayah & varchar $(80)$ & latin1_swedish_ci & & Tidak & & & 覧 & $\rho x$ & 殶 & [0] & 河 & 汿 \\
\hline$\square$ & Nama_Ibu & varchar(80) & latin1_swedish_ci & & Tidak & & & 雷 & $\int x$ & 需 & [0 & 颗 & 通 \\
\hline$\square$ & Alamat_ortu & text & latin1_5wedish_ci & & Tidak & & & 嶵 & $\Rightarrow x$ & in & (T) & $\pi$ & 臣 \\
\hline$\square$ & Telp_Ortu & varchar(20) & latin1_5wedish_ci & & Tidak & & & 菛 & $x$ & 露 & 四 & 玟 & ET \\
\hline$\square$ & pa & varchar(25) & latin1_swedish_ci & & Tidak & & & 圂 & $x$ & 霓 & 间 & $B$ & TT \\
\hline$\square$ & status & varchar(2) & latin1_swedish_ci & & Tidak & 0 & & 眯 & $=x$ & 麗 & [iv & 咸 & 臣 \\
\hline
\end{tabular}

\section{Gambar 8 Implemetasi Struktur Tabel Mahasiswa}

3) Tabel matakuliah

\begin{tabular}{|c|c|c|c|c|c|c|c|c|}
\hline & Field & Jenis & Penyortiran & Atribut & Kosong & Default & Ekstra & Aksi \\
\hline$\square$ & kode mk & varchar $(10)$ & latin1_swedish_ci & & Tidak & & & 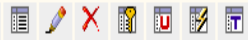 \\
\hline$\square$ & matkul & varchar(50) & latin1_swedish_ci & & $Y_{a}$ & NOLL & & 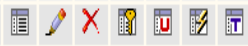 \\
\hline$\square$ & sks & int(11) & & & Ya & NULL & & 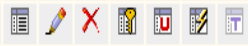 \\
\hline$\square$ & status & varchar(20) & latin1_swedish_ci & & Ya & NULL & & 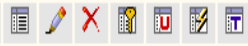 \\
\hline$\square$ & aktif & varchar(2) & latin1_swedish_ci & & Tidak & & & 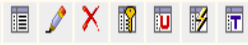 \\
\hline$\square$ & status_spk & varchar(20) & latin1_swedish_ci & & Tidak & & & 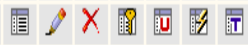 \\
\hline$\square$ & semester & $\operatorname{int}(1)$ & & & Tidak & & & 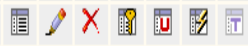 \\
\hline$\square$ & standar_nilai & $\operatorname{int}(1)$ & & & Tidak & & & 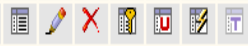 \\
\hline$\square$ & kode_kelompok_mk & varchar(5) & latin1_swedish_ci & & Tidak & & & 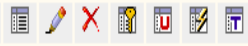 \\
\hline
\end{tabular}

Gambar 9 Implementasi Struktur Tabel Matakuliah

4) Tabel kelompok matakuliah

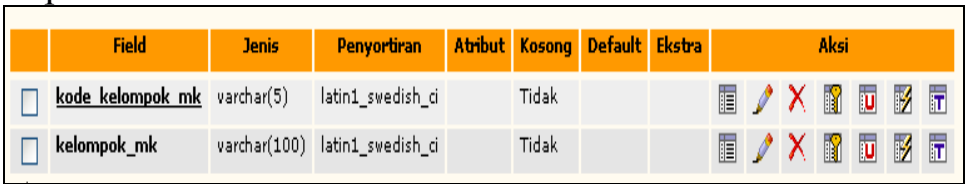

Gambar 10 Implementasi Struktur Tabel Kelompok Matakuliah

5) Tabel matakuliah prasyarat

\begin{tabular}{|c|c|c|c|c|c|c|c|c|}
\hline & Field & Jenis & Penyortiran & Atribut & Kosong & Default & Ekstra & Aksi \\
\hline$\square$ & id mk prasyarat & $\operatorname{int}(11)$ & & & Tidak & & auto_increment & 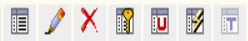 \\
\hline$\square$ & kode_mk & varchar(10) & latin1_swedish_ci & & Tidak & & & 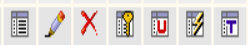 \\
\hline$\square$ & ket & text & latin1_swedish_ci & & Tidak & & & 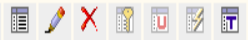 \\
\hline
\end{tabular}

Gambar 11Implementasi Struktur Tabel Matakuliah Prasyarat

6) Tabel matakuliah prasyarat khusus 


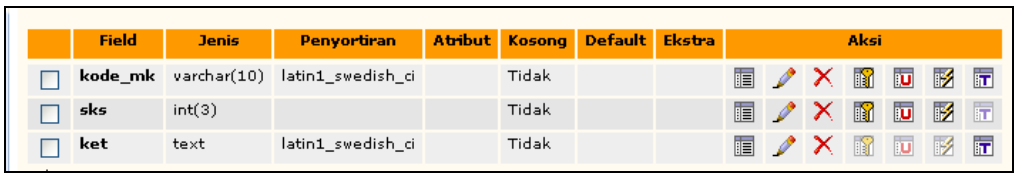

Gambar 12 Implementasi Struktur Tabel Matakuliah Prasyarat Khusus

7) Tabel matakuliah syarat

\begin{tabular}{|c|c|c|c|c|c|c|c|c|}
\hline & Field & Jenis & Penyortiran & Atribut & Kosong & Default & Ekstra & Aksi \\
\hline$\square$ & id_mk_prasyarat & $\operatorname{int}(11)$ & & & Tidak & & & 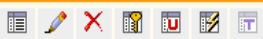 \\
\hline$\square$ & kode_mk & varchar(10) & latin1_swedish_ci & & Tidak & & & 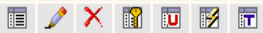 \\
\hline
\end{tabular}

Gambar 13 Struktur Tabel Matakuliah Syarat

8) Tabel nilai

\begin{tabular}{|c|c|c|c|c|c|c|c|c|c|c|c|c|c|c|}
\hline & Field & Jenis & Penyortiran & Atribut & Kosong & Default & Ekstra & \multicolumn{7}{|c|}{ Aksi } \\
\hline$\square$ & nim & varchar(15) & latin1_swedish_ci & & Ya & muLL & & 闻 & 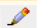 & $x$ & 閧 & 园 & 閔 & 击 \\
\hline$\square$ & kode_mk & varchar $(10)$ & latin1_swedish_ci & & $\gamma_{a}$ & MULL & & 闆 & 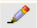 & $x$ & 䦗 & 园 & 蕆 & 囸 \\
\hline$\square$ & thn & varchar(20) & latin1_swedish_ci & & Ya & MULL & & 賗 & 8 & $x$ & 費 & 可 & 閣 & 囯 \\
\hline$\square$ & nilai & int(11) & & & $\gamma_{a}$ & 0 & & 囬 & 8 & $x$ & 開 & 可 & 咸 & 囯 \\
\hline$\square$ & nilai 1 & varchar(2) & latin1_swedish_ci & & Ya & muLL & & 闻 & 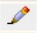 & $x$ & 圆 & 国 & 閣 & 粗 \\
\hline$\square$ & akum_nilai & $\operatorname{int}(20)$ & & & Ya & 0 & & 闻 & 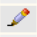 & $x$ & 阅 & 囦 & 国 & T \\
\hline$\square$ & NIP & varchar(20) & latin1_swedish_ci & & Ya & MULL & & 闻 & 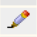 & $x$ & 盛 & 圆 & 㬝 & 园 \\
\hline$\square$ & smt & varchar $(10)$ & latin1_swedish_ci & & Ya & MULL & & 酎 & 8 & $x$ & 䦮 & 四 & 蕆 & 粗 \\
\hline
\end{tabular}

Gambar 14 Implmentasi Struktur Tabel Nilai

9) Tabel atribut

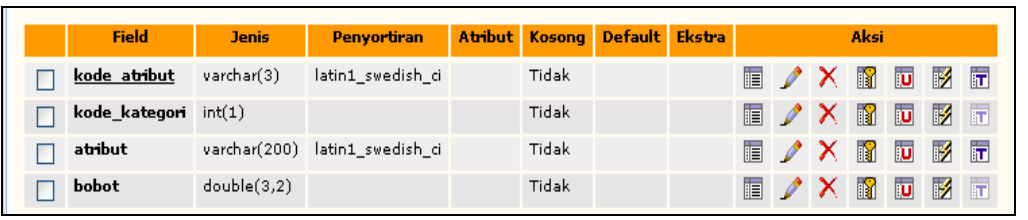

15 Implementasi Struktur Tabel Atribut

10) Tabel variabel atribut

\begin{tabular}{|c|c|c|c|c|c|c|c|c|c|c|c|c|c|c|}
\hline & Field & Jenis & Penyortiran & Atribut & Kosong & Default & Ekstra & \multicolumn{7}{|c|}{ Aksi } \\
\hline$\square$ & kode_variabel_atribut & varchar(4) & latin1_swedish_ci & & Tidak & & & & 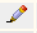 & $x$ & & 可 & 䀛 & 罡 \\
\hline$\square$ & kode_atribut & varchar(3) & latin1_swedish_ci & & Tidak & & & 罡 & 8 & $x$ & 盛 & 四 & 四 & 囯 \\
\hline$\square$ & variabel_atribut & varchar(200) & latin1_swedish_ci & & Tidak & & & 艦 & 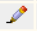 & $x$ & 栭 & 四 & 目 & 四 \\
\hline$\square$ & bobot & double $(3,2)$ & & & Tidak & & & 覧 & 8 & $x$ & 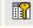 & 罒 & 橉 & 汿 \\
\hline$\square$ & keterangan & text & latin1_swedish_ci & & Tidak & & & 㘣 & 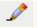 & $x$ & 得 & 四 & 图 & 畨 \\
\hline
\end{tabular}

Gambar 16 Implementasi Struktur Tabel Variabel Atribut

\subsection{Implementasi Antarmuka}

Implementasi layar antarmuka halaman SPK Berbasis Mobile untuk Pengisian KRS dapat dilihat pada Gambar 17. 


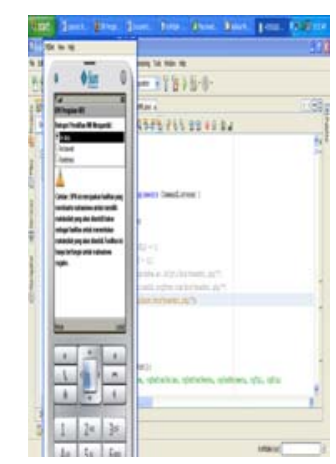

Gambar 17 Implementasi Layar Antarmuka HalamanUtama SPK Berbasis Mobile Untuk Pengisian KRS

\section{PENUTUP}

Berdasarkan hasil analisis, perancangan, dan implementasi di depan dapat disimpulkan beberapa hal sebagai berikut.

1) Rancangan sistem perangkat lunak SPK berbasis mobile untuk pengisian KRS digambarkan dengan menggunakan Data Flow Diagram (DFD). DFD ini mengambarkan bagaimana arus data di dalam sistem secara terstruktur dan jelas.

2) Impementasi SPK berbasis mobile untuk pengisian KRS menghasilkan informasi daftar matakuliah yang disarankan dan tidak disarankan serta menghasilkan daftar pemetaan matakuliah pada semester selanjutnya. Dengan adanya informasi tersebut dapat membantu mahasiswa dalam pemilihan matakuliah pada saat pengisian KRS sehingga pengisian KRS dapat berjalan dengan baik dan lancar. Sedangkan untuk menjalankan SPK berbasis mobile ini membutuhkan handphone yang mendukung Java minimal MIDP 2.0, dan GPRS.

\section{DAFTAR PUSTAKA}

Akid, Faisal. 2009. "Sistem Pendukung Keputusan”. http://teknikinformatika.com/sistem-pendukung-keputusan/ (diakses tanggal 17 Pebruari 2011).

Kusumadewi, Sri et.al. 2006. Fuzzy Multiple-Attribute Decision Making (Fuzzy $M A D M)$. Yogyakarta: Penerbit Graha Ilmu.

Kusrini. 2007. Konsep dan Aplikasi Sistem Pendukung Keputusan. Yogyakarta:Penerbit Andi.

Laymond, Rajim. 2010. "Komponen Sistem Pendukung Keputusan". http://sindarku.wordpress.com/2010/10/08/komponen-sistem-pendukungkeputusan-bag-4/ (diakses tanggal 22 Maret 2011).

Oracle. 2011. "Java ME Technology". http://www.oracle.com/technetwork/java/ javame/tech/index.html (diakses tanggal 22 Maret 2011).

Prasetijo, Agung Budi et.al. 2005. "Simulasi Aplikasi Java 2 Platform Micro Edition (J2ME) - Java Midlet Pada Jadwal Ujian". http://www.elektro.undip.ac.id/transmisi/des05/agungbpdes05.PDF $\quad$ (diakses tanggal 22 Maret 2011).

Wibowo S, Henry et.al. 2009. "Sistem Pendukung Keputusan untuk Menentukan PenerimaBeasiswa Bank BRI Menggunakan FMADM (Studi Kasus: Mahasiswa Fakultas Teknologi Industri Universitas Islam Indonesia)". 
http://journal.uii.ac.id/index.php/Snati/article/viewFile/1073/998 (diakses tanggal 17 Pebruari 2011).

Wijaya, Arif et.al. 2009. "Layanan Informasi Pembayaran Kuliah Berbasis SMS Interaktif". $\quad$ http://journal.uii.ac.id/index.php/Snati/article/viewFile/950/911 (diakses tanggal 22 Maret 2011). 